\title{
0-GIcNAc modification on IRS-1 and Akt2 by PUGNAc inhibits their phosphorylation and induces insulin resistance in rat primary adipocytes
}

\author{
Seung Yoon Park ${ }^{1}$, Jiwon Ryu ${ }^{2}$ and \\ Wan Lee Le $^{1,3}$ \\ ${ }^{1}$ From the Department of Biochemistry \\ College of Medicine, Dongguk University \\ Gyeongju 780-714, Korea \\ ${ }^{2}$ Biophysics Laboratory \\ Veteran Affairs Medical Center \\ Department of Physiology and Biophysics \\ School of Medicine, State University of New York at Buffalo \\ Buffalo, NY 14215, USA \\ ${ }^{3}$ Corresponding author: Tel, 82-54-770-2409; \\ Fax, 82-54-770-2447; E-mail, wanlee@dongguk.ac.kr
}

Accepted 7 June 2005

Abbreviations: GLUT, glucose transporter; HBP, hexosamine biosynthetic pathway; IRS, insulin receptor substrate; PDK-1, phosphatidylinositol dependent protein kinase-1; PKC- $\lambda / \zeta$, protein kinase $\mathrm{C}-\lambda / \zeta$; PI3K, phospatidylinositol 3-kinase; PM, plasma membrane

\footnotetext{
Abstract

It has been known that $\mathrm{O}$-linked $\beta$ - $N$-acetylglucosamine $(0-G I c N A c)$ modification of proteins plays an important role in transcription, translation, nuclear transport and signal transduction. The increased flux of glucose through the hexosamine biosynthetic pathway (HBP) and increased $0-$ GICNAC modification of protein have been sug. gested as one of the causes in the development of insulin resistance. However, it is not clear at the molecular level, how 0 -GIcNAc protein modification results in substantial impairment of insulin signaling. To clarify the association of 0 . GICNAc protein modification and insulin resistance in rat primary adipocytes, we treated the adipocytes with 0 -(2-acetamido-2deoxy-D-glucopyranosylidene)am in $0-N$ - phen y lc a rbam a te (PUGNAC), a potent inhibitor of 0 -GIcNAcase that catalyzes removal of $0-$ GICNAc from proteins. Prolonged treatment of PUGNAC $(100 \mu \mathrm{M}$ for 12 h) increased 0. -GICNAc modification on proteins in adipocytes. PUGNAC also drastically decreased insulin-stimulated 2-deoxyglucose (2DG) uptake and GLUT4 translocation in adipocytes, indicat-
}

ing that PUGNAc developed impaired glucose utilization and insulin resistance in adipocytes. Interestingly, the 0-GIcNAc modification of IRS-1 and Akt2 was increased by PUGNAc, accom. panied by a partial reduction of insulin-stimulated phosphorylations of IRS-1 and Akt2. The PUGNAC treatment has no effect on the expression level of GLUT4, whereas 0-GICNAC modification of GLUT4 was increased. These results suggest that the increase of $0-$ GIcNAc modification on insulin signal pathway intermediates, such as IRS-1 and Akt2, reduces the insulin-stimulated phosphorylation of IRS-1 and Akt2, subsequently leading to insulin resistance in rat primary adipocytes.

Keywords: Akt2; GLUT4; insulin resistance; IRS-1; O-GICNAc; PUGNAC

\section{Introduction}

The pathophysiology of non-insulin-dependent diabetes mellitus (NIDDM) results from impaired peripheral tissue sensitivity to insulin and reduction of insulin secretion. Glucose uptake in mammalian cells is mediated by a family of intrinsic membrane proteins known as facilitative glucose transporters, GLUTs (Mueckler, 1994). GLUT4, the insulin-responsive glucose transporter, is selectively expressed in adipocytes and muscle (Bryant et al., 2002). GLUT4 in these cells constantly recycles between the plasma membrane (PM) and intracellular storage pools (Cushman and Wardzala, 1980). About 90 percent of GLUT4 is sequestered intracellularly in the absence of insulin or other stimuli such as exercise (Cushman and Wardzala, 1980). Insulin stimulates glucose uptake in these cells primarily by inducing net translocation of GLUT4 from the intracellular storage sites to the PM (Lee et al., 1999, Lee et al., 2000b). The translocation of GLUT4 by insulin results from a cascade of signal transduction, which is composed of a series of molecules (Pessin et al., 1999). Insulin-stimulated GLUT4 translocation and glucose uptake are mediated largely through the activation/phosphorylation of IRS-1 and its downstream effectors, such as PI3K, PDK-1, PKC- $\lambda / \zeta$, and Akt2 (Saltiel and Pessin, 2002; Kanzaki and Pessin, 2003). An impaired GLUT4 translocation and/or insulin signaling pathway would result in insulin resistance and hyperglycemia, the primary characteristics and hallmarks of NIDDM (Watson and Pessin, 2001). 
It has been known that O-GIcNAc modification of protein plays an important role in transcription, translation, nuclear transport and cytoskeletal assembly (Comer and Hart, 2000; Wells et al., 2001). Recently, O-GICNAc modification as well as phosphorylation/ dephosphorylation has been focused on as a main regulation mechanism of cellular signal transduction pathways. Post-translational O-GIcNAc modification on proteins is defined as the $O$-linked attachment of single GIcNAc moiety to specific hydroxyl groups of Ser or Thr residue (Buse et al., 2002). Since Oglycosylation of cellular proteins via Ser/Thr takes place dynamically in various ways and the modification site is usually located near the $O$-phosphorylation site or sometimes at the same site, O-GIcNAc modification plays as a dynamic negative regulator against protein phosphorylation (Snow and Hart, 1998, Zachara and Hart, 2002). Therefore, O-glycosylation and O-phosphorylation are known to participate in the modification of protein interaction and regulation of signal transduction by changing the protein reaction site through the mutual interaction (Griffith and Schmitz, 1999; Cheng et al., 2000).

With increasing knowledge about O-GIcNAc modification as a new regulatory signal, there have been reports that abnormalities in the regulation of $\mathrm{O}$ GlcNAc protein modification are one of the causes in the pathogenesis of NIDDM. Marshall et al. (1991) first implicated HBP in glucose-induced insulin resistance by demonstrating a requirement for the enzyme, glutamine fructose 6-phosphate amidotransferase (GFAT). The metabolic step catalyzed by GFAT provides the necessary substrates for protein modification by O-GIcNAc. Subsequently, the infusion of glucosamine induced insulin resistance in rat by increasing uridine diphosphate- $\mathrm{N}$-acetylglucosamine (UDP-GIcNAc) levels (Rossetti et al., 1995), and the transgenic mice over-expressing GFAT also developed insulin resistance with high GFAT activity and UDP-GIcNAc levels (Hebert et al., 1996). O-Glycosylation of several proteins was increased by the O-GIcNAc infusion in rats (Yki-Jarvinen et al., 1998), and insulin-stimulated GLUT4 translocation to the PM was inhibited by high glucosamine treatment in rat skeletal muscle (Baron et al., 1995). In addition to UDP-GICNAC flux, the overexpression of O-GIcNAc transferase, an enzyme catalyzing the addition of $O$ GlcNAc on target proteins, induced insulin resistance and hyperleptinemia in transgenic mice (McClain et al., 2002). This result suggests that GIcNAc transferase participates in a hexosamine-dependent signaling pathway that is linked to insulin resistance and leptin production. O-GIcNAcase, an nucleocytoplasmic enzyme catalyzing removal of O-GIcNAc from proteins, is suggested as an another important modulator involved in O-GIcNAc modifications on target proteins (Dong and Hart, 1994, Wells et al., 2001). PUGNAc, a GlcNAc analogue, potently inhibited O-GIcNAcase and induced globally elevated O-GICNAc modification of proteins without altering $N$-linked glycosylation or UDP-GIcNAc levels (Haltiwanger et al., 1998). It has been reported that the administration of PUGNAC increased cellular O-GICNAc modification of proteins and also induced insulin resistance in 3T3-L1 adipocytes (Vosseller et al., 2002) and rat skeletal muscle (Arias et al., 2004). These results indicate that either activation of O-GICNAc transferase or inhibition of $\mathrm{O}$ GIcNAcase increases O-GICNAc modification on proteins, and subsequently attenuates insulin signaling in peripheral tissues such as muscle and adipocytes.

Recently, Vosseller et al. (2002) demonstrated that PUGNAC induces insulin resistance by reducing insulin-stimulated phosphorylation of Akt and glycogen synthase kinase $3 \beta$ (GSK3 $\beta$ ) in 3T3-L1 adipocytes. However, Arias et al. (2004) suggest that PUGNAcinduced insulin resistance is not attributable to reduced phosphorylation of Akt or GSK3 $\alpha / \beta$ in rat skeletal muscle. There is also a report that the glucosamine-induced insulin resistance is closely associated with increased O-GICNAc modification and reduced tyrosine phosphorylation of IRS-1 and -2 in rat skeletal muscle (Patti et al., 1999). This evidence revealed that 0 -GIcNAc modification on proteins by PUGNAc causes insulin resistance in muscle and adipocytes (Haltiwanger et al., 1998; Gao et al., 2000; Vosseller et al., 2002; Arias et al., 2004). However, it is not clear how and which O-GICNAc modification of proteins causes substantial disturbances in glucose uptake and insulin signaling, leading to insulin resistance in rat adipocytes.

In the present study, we report that treatment of PUGNAC is directly correlated with the elevation of $O-G I c N A c$ protein modification and insulin resistance in rat primary adipocytes. Prolonged treatment of PUGNAC increased O-GICNAc modification on several proteins and partially inhibited insulin-stimulated 2DG uptake and GLUT4 translocation. The O-GICNAC modification of IRS-1 and Akt2 was increased by PUGNAc, accompanied by a partial reduction of insulin-stimulated phosphorylations of IRS-1 and Akt2. It is suggested that the increase of O-GIcNAc modification on insulin signal pathway intermediates, such as IRS-1 and Akt2, and the reduction in insulin-stimulated phosphorylation of IRS-1 and Akt2 are associated with the insulin resistance developed in PUGNActreated rat primary adipocytes.

\section{Materials and Methods}

\section{Materials}

Collagenase type I was obtained from Worthington (Lakewood, NJ). The anti-O-GIcNAc antibody designated as CTD110.6 was purchased from Covance (Princeton, NJ). Anti-GLUT4 antibody (clone 1F8) was purchased from Biogenesis Ltd. (Sandown, NH). Antibodies against IR, IRS-1, PI3K, Akt2, and PDK1 were purchased from Upstate (Lake Placid, NY). Antibody against phospho-Tyr IRS-1 was a generous gift from Dr. Pann-Gill Suh (Postech, Pohang, Korea). Anti-phospho-Ser Akt2 antibody was from Cell Signaling (Beverly, MA). Horseradish peroxidase (HRP)labeled goat anti-mouse $\operatorname{lgM}$ as a secondary antibody 
for CTD110.6 immunoblot was from Sigma (St. Louis, $M O)$. HRP-labeled protein $A$ and anti-mouse $\lg G$ were obtained from Zymed Laboratories Inc. (San Francisco, CA). PUGNAc was purchased from Carbogen Labs (Aarau, Switzerland). Reagents and apparatus for SDS-PAGE and immunoblotting were obtained from Bio-Rad (Richmond, CA). Except for individually stated, all other chemicals were from Sigma.

\section{Adipocytes preparation and subcellular fractionation}

All animal experiment procedures were carried out in accordance with the principles of laboratory animal care and with the approval of the ethical committee. Primary adipocytes were isolated from epididymal fat pads of male Sprague-Dawley rats $(180-200 \mathrm{~g})$ and stabilized as described (Liu et al., 1995; Kim et al., 2004a). Adipocytes were cultured for $0,3,6$ and 12 $\mathrm{h}$ in Krebs-Ringer's phosphate buffer (KRB: $128 \mathrm{mM}$ $\mathrm{NaCl}, 4.7 \mathrm{mM} \mathrm{KCl}, 1.25 \mathrm{mM} \mathrm{CaCl}_{2}, 1.25 \mathrm{mM} \mathrm{MgSO}_{4}$, $1 \mathrm{mM} \mathrm{Na}_{2} \mathrm{HPO}_{4}$ at $\mathrm{pH} 7.4$ ) supplemented with $4 \mathrm{mM}$ glucose in the absence or presence of PUGNAc. When insulin was used, adipocytes were treated with insulin $(30 \mathrm{nM})$ for last $20 \mathrm{~min}$ during incubation. Subcellular membrane fractions enriched with PM and low-density microsomes (LDM) were prepared after homogenation as described (Martz et al., 1986).

\section{Immunoprecipitation}

For whole-cell lysates used in immunoprecipitation, adipocytes were washed twice with KRB and homogenized with $1 \%$ Nonidet $\mathrm{P}-40$ buffer containing 15 $\mathrm{mM}$ Tris- $\mathrm{HCl}(\mathrm{pH} \mathrm{7.4),} 150 \mathrm{mM} \mathrm{NaCl}, 1 \mathrm{mM}$ EDTA, protease inhibitors $(1 \mathrm{mM}$ benzamidine, $0.2 \mathrm{mM}$ PMSF, $10 \mu \mathrm{M}$ E-64, $1 \mu \mathrm{M}$ pepstatin $\mathrm{A}$ and $1 \mu \mathrm{M}$ leupeptin), phosphatase inhibitors (1 $\mathrm{mM} \mathrm{Na}_{2} \mathrm{VO}_{4}$ and $100 \mathrm{nM}$ okadaic acid), and $1 \mu \mathrm{M}$ PUGNAc. Homogenates were centrifuged first at $500 \mathrm{~g}$ for $10 \mathrm{~min}$ to remove the fat cake and insoluble substances, and then the dissolved materials were centrifuged at $185,000 \mathrm{~g}$ for $2 \mathrm{~h}$ to obtain the whole-cell lysates. Immunoprecipitations with specified antibodies were performed overnight (CTD110.6) or $4 \mathrm{~h}$ (anti-IRS-1 and Akt2) at $4^{\circ} \mathrm{C}$ according to the previously described (Vosseller et al., 2002). Immunoprecipitation of GLUT4 was performed as described previously (Lee et al., 2000a) with modifications. 1F8 or normal mouse IgG was coupled to Tris-acryl beads (Reacti-Gel GF2000, Pierce) at a concentration of $1.0 \mathrm{mg}$ of antibody/ml of resin according to the manufacturer's instructions. The antibody-coupled beads were quenched by $2 \mathrm{M}$ Tris $(\mathrm{pH} 8.0)$ for $1 \mathrm{~h}$, incubated with $2 \%$ BSA in PBS (134 mM NaCl, $2.6 \mathrm{mM} \mathrm{KCl}, 6.4 \mathrm{mM}$ $\mathrm{Na}_{2} \mathrm{HPO}_{4}, 1.46 \mathrm{mM} \mathrm{KH}_{2} \mathrm{PO}_{4}, \mathrm{pH}$ 7.4) for $2 \mathrm{~h}$ to prevent non-specific binding, and washed 5 times with $1 \mathrm{ml}$ of PBS at room temperature. $300 \mu \mathrm{g}$ of LDM were incubated with $90 \mu \mathrm{l}$ of beads in $500 \mu \mathrm{l}$ of PBS containing $1 \%$ Triton $X-100$ overnight at $4^{\circ} \mathrm{C}$, and unbound supernatants were collected for analysis. Beads were washed 5 times with $1 \mathrm{ml}$ of PBS at $4^{\circ} \mathrm{C}$ and then the adsorbed material was eluted with SDS $(2 \%)$-containing Laemmli buffer without $\beta$-mercaptoethanol for $1 \mathrm{~h}$ at room temperature.

\section{Determination of 2-deoxyglucose (2DG) uptake}

Adipocytes were washed twice with Hepes-buffered saline solution $(140 \mathrm{mM} \mathrm{NaCl}, 20 \mathrm{mM}$ Hepes/ $\mathrm{Na}, 2.5$

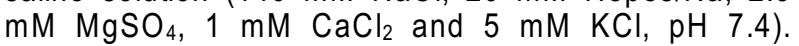
2DG was measured as described previously (Sweeney et al., 1999). Briefly, cells were incubated for 15 $\mathrm{min}$ in the presence or absence of insulin (30 nM) and then 2DG uptake $\left(10 \mu \mathrm{M}\left[{ }^{14} \mathrm{C}\right] 2 \mathrm{DG}, 1 \mu \mathrm{Ci} / \mathrm{ml}\right.$, NEN Life Science) was measured for $3 \mathrm{~min}$. Nonspecific uptake was determined in the presence of 10 $\mu \mathrm{M}$ cytochalasin $\mathrm{B}$ and was subtracted from all values.

\section{Gel electrophoresis and immunoblotting}

Membranes solubilized in Laemmli solution were subjected to SDS-PAGE on 8 or $10 \%$ resolving gels as described (Laemmli, 1970; Kim et al., 2004b). Separated proteins were electrophoretically transferred to nitrocellulose membrane (Bio-Rad, Hercules, CA), blocked with $5 \%$ nonfat milk in Tris-buffered saline, and incubated with primary antibodies in TTBS (Trisbuffered saline plus $0.05 \%$ Tween 20 ) containing $1 \%$ non-fat milk. After overnight incubation, membranes were washed with TTBS and incubated with horseradish peroxidase-labeled protein $A$ (for the detection of polyclonal antibodies) or horseradish peroxidaselabeled anti-mouse $\lg G$ (for the detection of monoclonal antibodies). Proteins were visualized using enhanced chemiluminescent substrate kit (NEN Life Science Products). Immunoblot intensities were quantitated by densitometry using an analytical scanning system (Molecular Dynamics Inc., Sunnyvale, CA).

\section{Statistical analysis}

Values are expressed as the mean \pm SEM. Where applicable, the significance of difference was analyzed using Student's $t$ test for unpaired data.

\section{Results}

To develop O-GIcNAc protein modifications, we exposed the primary adipocytes isolated from epidermal fat tissue to PUGNAC $(100 \mu \mathrm{M})$ for $0,3,6$, and 12 $\mathrm{h}$ at $37^{\circ} \mathrm{C}$. The whole-cell lysates separated on SDSPAGE were visualized through silver staining and immunoblotting with the O-GICNAc-specific antibody CTD110.6 (Figure 1A). The total protein levels in whole-cell lysates were not affected by PUGNAC treatment, whereas O-GIcNAc levels determined by immunoblotting were considerably increased in wholecell lysates treated with PUGNAc for $12 \mathrm{~h}$. We also treated primary adipocytes with varying concentrations of PUGNAc with fixed incubation time (12 h). The O-GIcNAc modification levels were determined by immunoblotting with CTD110.6, and the relative im- 
A

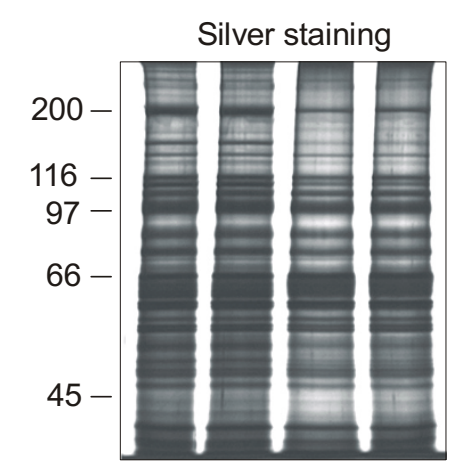

Time (h) $\quad 0 \quad 3 \quad 6 \quad 12$

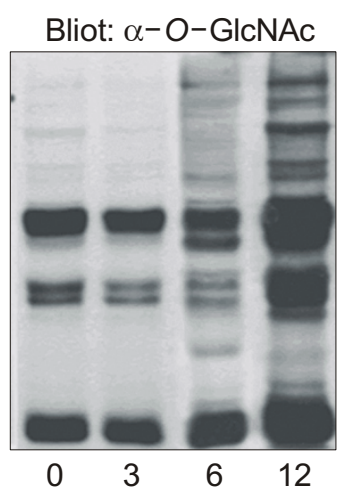

B

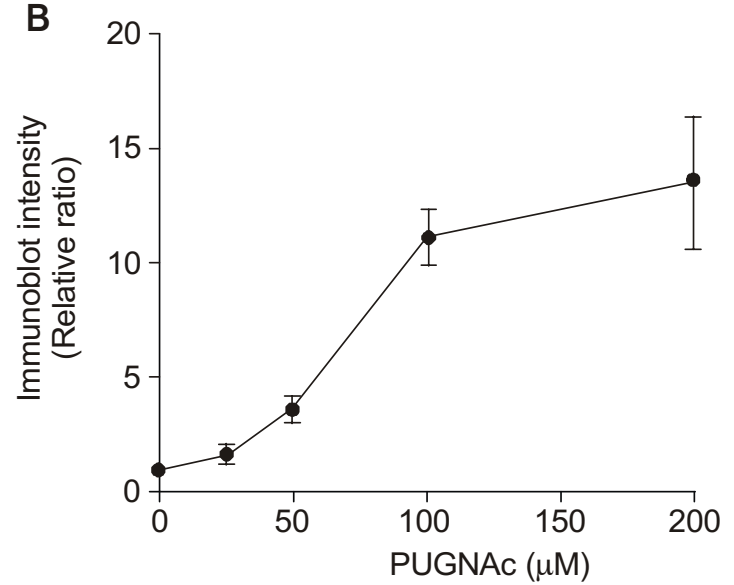

Figure 1. Effect of PUGNAc on O-GICNAc modification in rat adipocytes. Panel A: Adipocytes from rat epididymal fat tissue were isolated and incubated for indicated time (Hrs) in the presence or absence of $100 \mu \mathrm{M}$ of PUGNAc as described in Materials and Methods. $50 \mu \mathrm{g}$ of whole-cell lysates were separated on $8 \%$ SDS-PAGE and subjected to silver staining and immunoblotting against 0-GIcNAc-specific antibody. The result shown here was representative from five independent experiments. Panel B: Adipocytes were incubated for $12 \mathrm{~h}$ with the indicated concentration of PUGNAc (closed circles). Adipocytes without PUGNAc treatment were used as reference immunoblot intensity. 0-GlcNAc level per $50 \mu \mathrm{g}$ of whole-cell lysate was determined by immunoblotting using CTD110.6 antibody. All data points are mean \pm SEM from five independent experiments.
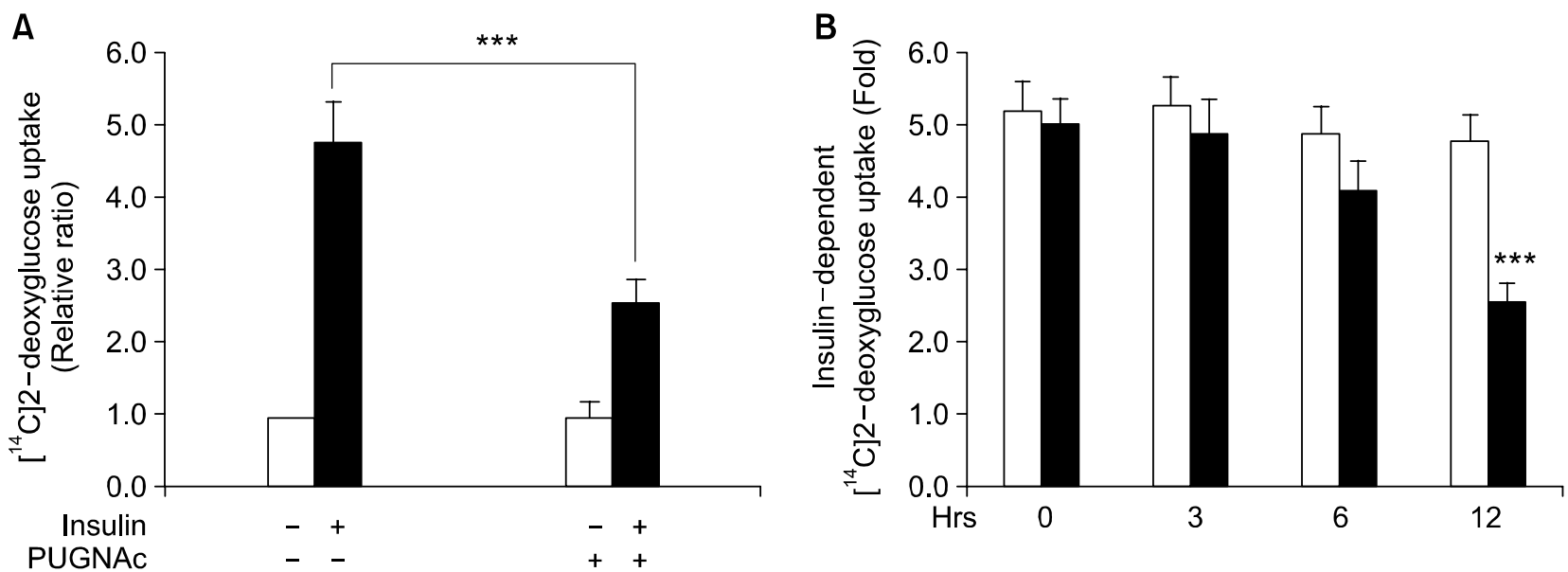

Figure 2. Effect of PUGNAc on 2DG uptake in rat adipocytes. Panel A: Adipocytes were incubated for $12 \mathrm{~h}$ in the presence or absence of $100 \mu \mathrm{M}$ of PUGNAc. For insulin stimulation, adipocytes were incubated in the presence of insulin $\left(30 \mathrm{nM}\right.$ at $\left.37^{\circ} \mathrm{C}\right)$ for last 15 min of culture. 2DG uptake (for 3 min with $10 \mu \mathrm{M}\left[{ }^{14} \mathrm{C}\right] 2 \mathrm{DG}$ ) was measured as described in Materials and Methods. Non-specific uptake was determined in the presence of $10 \mu \mathrm{M}$ cytochalasin $B$ and was subtracted from all values. Data were expressed in arbitrary units where the radioactivity for basal control was set to one. Values are for basal (open column) and insulin-stimulated (closed column) adipocytes, expressed as mean \pm SEM from five independent experiments. ${ }^{* * *} P<0.001 \mathrm{vs}$ basal control. Panel B: Adipocytes were incubated for $0,3,6$, and $12 \mathrm{~h}$ in the presence or absence of $100 \mu \mathrm{M}$ of PUGNAc, and then 2DG was measured as described in Panel A. Then, insulin-dependent 2DG uptake was calculated in fold change where the radioactivity for basal 2DG uptake was set to one. Values for control (open column) and PUGNAc-treated (closed column) adipocytes expressed as mean \pm SEM from three independent experiments. ${ }^{* * *} P<0.001$ vs control.

munoblot intensities against control cells were obtained (Figure 1B). The maximal increase appeared at $100 \mu \mathrm{M}$ PUGNAc. No further increase in GICNAC levels was seen in cells treated with higher PUGNAC concentrations up to $200 \mu \mathrm{M}$. Since the viability and morphology of adipocytes were not affected by PUGNAc treatment (data not shown), it suggests that the treatment of $100 \mu \mathrm{M}$ PUGNAc for $12 \mathrm{~h}$ suc- cessfully induces 0 -GIcNAc modification on proteins in primary adipocytes.

To demonstrate how the increased O-GIcNAc modification by PUGNAc correlates with glucose transport activity in rat primary adipocytes, we measured glucose uptake using radiolabeled 2DG in the adipocytes incubated with or without PUGNAc for $12 \mathrm{~h}$ (Figure $2 A)$. The basal glucose uptake in control was not 
significantly different from that in PUGNAc-treated adipocytes. Insulin stimulation $(30 \mathrm{nM}, 15 \mathrm{~min}$ at $37^{\circ} \mathrm{C}$ ) in control adipocytes increased 2DG uptake by 4.8-fold as compared with the basal state, whereas there was a significant reduction $(45 \%)$ in the insulin-stimulated 2DG uptake from PUGNAc-treated adipocytes as compared to that of control (Figure 2A), clearly indicating that PUGNAC developed insulin resistance in rat adipocytes. To confirm that the reduced 2DG uptake in PUGNAc-treated adipocytes is indeed correlated with O-GIcNAc level, we also measured 2DG uptakes from adipocytes incubated in the presence or absence of PUGNAc for various time periods such as $0,3,6$ and $12 \mathrm{~h}$ (Figure 2B). Insulin-dependent increases of 2DG uptake in controls were consistently as high as 5 -fold up to $12 \mathrm{~h}$, whereas PUGNAc decreased the insulin-stimulated 2DG uptake slightly at $6 \mathrm{~h}$ and significantly at $12 \mathrm{~h}$ (Figure 2B), clearly suggesting that the increase of

A

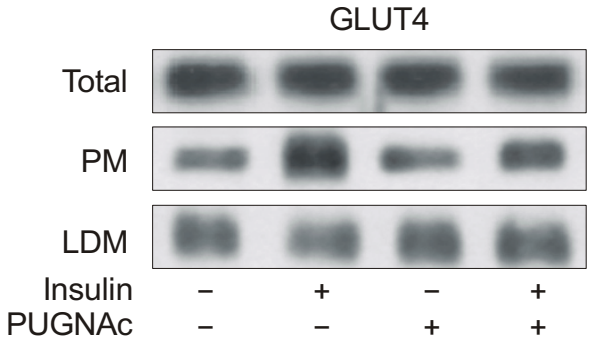

B

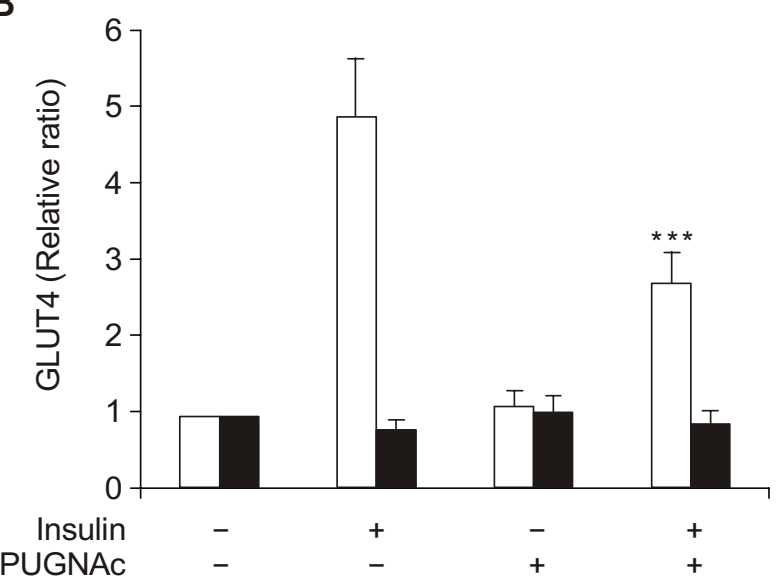

Figure 3. Effect of PUGNAC on the basal and insulin-stimulated GLUT4 translocation in rat adipocytes. Control and PUGNAc-treated $\left(100 \mu \mathrm{M}\right.$ for $12 \mathrm{~h}$ at $\left.37^{\circ} \mathrm{C}\right)$ adipocytes were incubated for last $15 \mathrm{~min}$ in the presence or absence of insulin $\left(30 \mathrm{nM}\right.$ at $\left.37^{\circ} \mathrm{C}\right)$. Plasma membrane (PM) and low density microsome (LDM) were prepared as described in Materials and Methods. Panel A: $5 \mu \mathrm{g}$ of membrane proteins were analyzed by SDS-PAGE and immunoblotting with antiGLUT4 antibody. Panel B: The protein levels obtained by densitometry from immunoblot intensity were expressed in relative ratio where the intensity for basal control was set to one. Values are expressed as mean \pm SEM from four independent experiments. PM GLUT4 (open column), LDM GLUT4 (closed column); ${ }^{* * *} P<0.001$.
O-GICNAc modification level in adipocytes is associated with the development of insulin resistance.

It has been known that the basal and insulin-stimulated glucose uptake in adipocytes mainly correlates with the amount of GLUT4 in the PM. Since insulin-stimulated 2DG uptake was significantly decreased by prolonged PUGNAc treatment (12 h) (Figure 2), we next assessed whether the O-GIcNAc modification in adipocytes is associated with the impaired insulin-stimulated GLUT4 translocation. As shown in Figure $3 \mathrm{~A}$, total cellular GLUT4 contents were not affected by PUGNAc treatment in adipocytes. Insulin substantially (about 5-fold) increased GLUT4 translocation to the PM in control, whereas the insulin-stimulated GLUT4 translocation in PUGNACtreated adipocytes was significantly reduced by $45 \%$ (Figures $3 \mathrm{~A}$ and $\mathrm{B}$ ). This indicates that $\mathrm{O}$-GIcNAc modification is closely associated with the impairment of insulin-stimulated GLUT4 translocation to the PM in adipocytes. These results implicate that PUGNAC partly impairs the insulin signaling pathway responsible for the insulin-stimulated GLUT4 translocation to the PM.

It is possible that the insulin resistance by PUGNAC may result from an alteration in the insulin signaling intermediates involved in GLUT4 translocation, including IR, IRS-1, PI3K, PDK-1, and their downstream effector, Akt2 (Kanzaki and Pessin, 2003, Saltiel and Pessin, 2002). Therefore, we immunoprecipitated 0 GIcNAc-modified proteins with a specific antibody CTD110.6 as described in Materials and Methods, and we assessed the O-GIcNAc modification of insulin

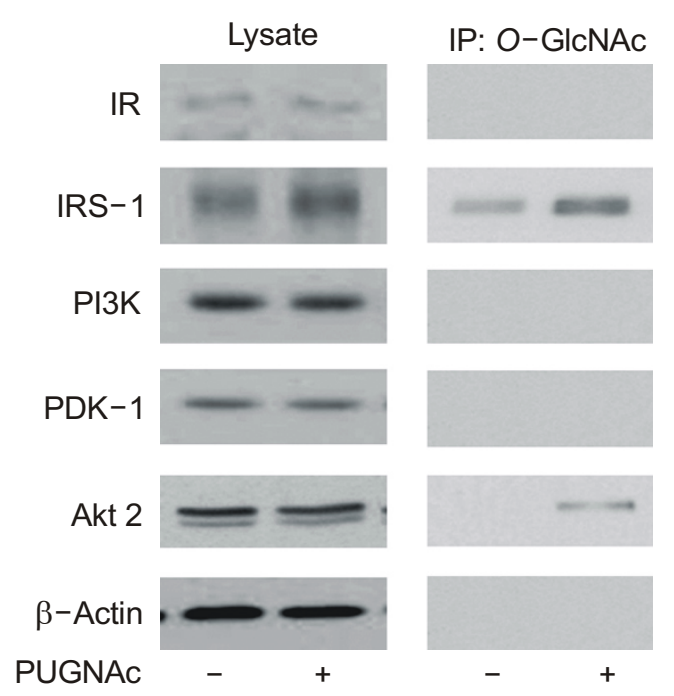

Figure 4. Effect of PUGNAc on the expression and O-GICNAc modification of insulin signaling intermediates. Adipocytes were incubated for $12 \mathrm{~h}$ in the presence or absence of $100 \mu \mathrm{M}$ of PUGNAc and whole-cell lysates were prepared. Whole-cell lysates were immunoprecipitated with CTD110.6 as described in Materials and Methods. Whole-cell lysates and immunoprecipitates (IP) were immunoblotted with indicated antibodies. The result shown here was representative from four independent experiments. 
A

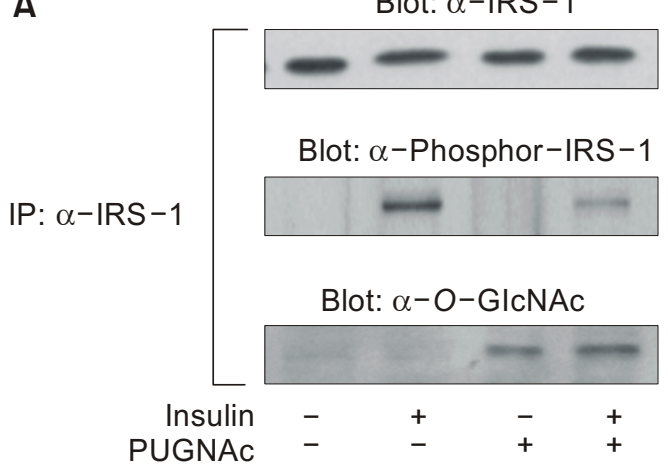

B

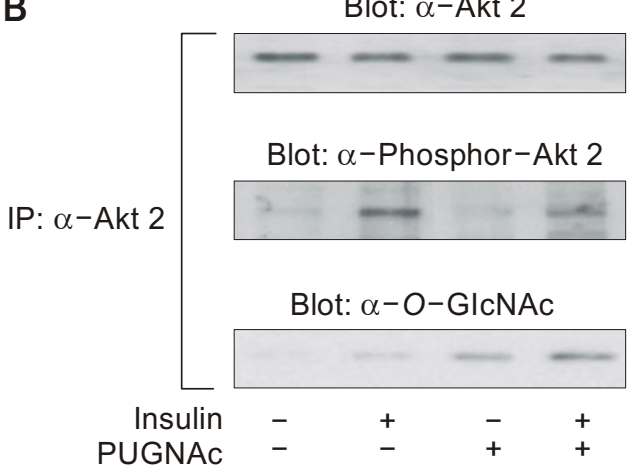

Figure 5. Effect of PUGNAc on the phosphorylation and 0-GICNAC modification of IRS-1 and Akt2. Adipocytes were incubated for $12 \mathrm{~h}$ in the presence or absence of $100 \mu \mathrm{M}$ of PUGNAc and whole-cell lysates were prepared. For insulin stimulation, adipocytes were incubated in the presence of insulin $\left(30 \mathrm{nM}\right.$ at $\left.37^{\circ} \mathrm{C}\right)$ for last 15 min of culture. Panel A: Whole-cell lysates were immunoprecipitated with anti-IRS-1 antibody and immunoprecipitates were immunoblotted with phospho-Tyr IRS-1 antibody or anti-0-GICNAC antibody. Panel B: Whole-cell lysates were immunoprecipitated with anti-Akt2 antibody and immunoprecipitates were immunoblotted with phospho-Ser Akt2 antibody or anti-0-GICNAc antibody. Normal IgG used as a non-specific bound control did not show any immunoblot intensity (data not shown). The result shown here was representative from four independent experiments.

signaling intermediates from the immunoprecipitates (Figure 4). PUGNAc did not change the protein expression levels of insulin signaling intermediates in whole-cell lysates. IR, PI3K and PDK-1 were not found in O-GIcNAc-specific immunoprecipitates, suggesting that $\mathrm{O}-\mathrm{GICNAC}$ modification of those proteins were not affected by PUGNAc treatment. However, immunoblot intensities of IRS-1 and Akt2 were clearly increased in anti-O-GICNAC immunoprecipitates from PUGNAc-treated adipocytes, indicating that PUGNAC selectively increased 0 -GIcNAc modification on IRS-1 and Akt2 in adipocytes.

Since PUGNAC increased O-GICNAC modification on IRS-1 and Akt2 as shown in Figure 4, we also assessed the effect of PUGNAc on the insulin-stimulated phosphorylation of IRS-1 and Akt2 in adipocytes. IRS-1 or Akt2 was immunoprecipitated from adipocytes lysates, after which the phosphorylation and 0 -GICNAC modification of IRS-1 and Akt2 were analyzed with the specific antibodies described in Materials and Methods (Figure 5A and B). Cellular insulin treatment in control drastically increased tyrosine phosphorylation of IRS-1 as compared with the basal level (Figure 5A). However, PUGNAc increased O-GIcNAc modification and suppressed insulin-stimulated tyrosine phosphorylation of IRS-1, suggesting that O-GIcNAc modification of IRS-1 is closely associated with the reduction of insulin-stimulated its phosphorylation. Next, we also assessed the involvement of Akt2 in impaired insulin-stimulated GLUT4 translocation by PUGNAc treatment, since phosphorylation of Akt2 has been known to play an important role in insulin-stimulated GLUT4 translocation by insulin (Saltiel and Pessin, 2002; Kanzaki and Pessin, 2003). In a similar experiment using immunoprecipitates by anti-Akt2 antibody, the total cellular content of Akt2 was not changed by insulin or PUGNAC treatment (Figure 5B). Insulin treatment drastically

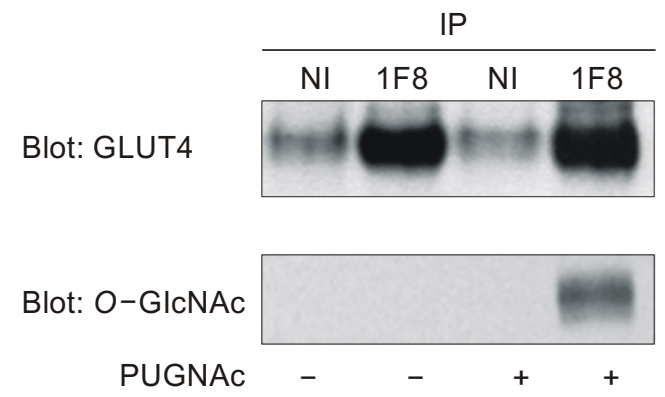

Figure 6. Effect of PUGNAc on the O-GICNAc modification of GLUT4 in rat adipocytes. Adipocytes were incubated for $12 \mathrm{~h}$ in the presence or absence of $100 \mu \mathrm{M}$ of PUGNAc, and LDM were prepared as described in Materials and Methods. $300 \mu \mathrm{g}$ of LDM were immunoprecipitated with normal mouse $\lg G$ (NI) or 1F8, GLUT4-specific monoclonal antibody (1F8), and immunoprecipitates were immunoblotted with polyclonal GLUT4 antibody or anti-O-GICNAc antibody. The result shown here was representative from three independent experiments.

increased the phosphorylation of Akt2 as compared with the basal level in control, whereas the insulinstimulated phosphorylation of Akt2 was drastically decreased by PUGNAc treatment. These results indicate that elevated 0 -GIcNAc modification inhibits insulin signaling pathways through interfering with the phosphorylation of IRS-1 and Akt2.

We also assessed whether PUGNAc increases OGIcNAc modification of GLUT4 in intracellular GLUT4 storage pools in rat adipocytes. Immunopurified GLUT4 from LDM fraction was subjected to Western blot analysis against 0 -GICNAc antibody (Figure 6). The O-GICNAc modification of immunopurified GLUT4 in control cells was under the detectable limit, whereas GLUT4 in PUGNAc-treated cells was substantially modified by $0-$ GICNAc. Since the direct effect of 0 GICNAc modification on GLUT4 is not immediately 
clear, the possible regulatory mechanism of GLUT4 translocation by O-GICNAC modification needs further investigation.

\section{Discussion}

It has been proposed that increased sugar influx into the cell via HBP induces insulin resistance by increasing proteoglycan production, lipid glycosylation, and O-GIcNAc protein modification (Brownlee, 2001). The increase of UDP-GIcNAc flux through HBP causes insulin resistance via the elevated O-GICNAc modification on target proteins and GFAT implicates in this process (Baron et al., 1995, Giaccari et al., 1995; Rossetti et al., 1995; Hebert et al., 1996). In addition to increases in UDP-GICNAc flux and GFAT activity, either activation of $\mathrm{O}-\mathrm{GICNAC}$ transferase or inhibition of $\mathrm{O}$-GIcNAcase increases $\mathrm{O}-\mathrm{GlcNAc}$ modification on proteins, and subsequently attenuates insulin signaling in insulin sensitive cells such as muscle and adipocytes (Haltiwanger et al., 1998; Vosseller et al., 2002; Arias et al., 2004). However, there is as yet no convincing evidence whether the increased $\mathrm{O}$ GIcNAc modification of proteins by O-GIcNAcase inhibition in primary adipocytes causes substantial disturbances in insulin signaling, and if any, which insulin signaling intermediates are involved in the development of insulin resistance.

To investigate the correlation between the $\mathrm{O}$ GIcNAc modification and insulin resistance in rat primary adipocytes, here we used PUGNAc, a nonmetabolizable analogue of glucosamine and potent inhibitor of O-GIcNAcase (Haltiwanger et al., 1998). Although concentration and duration of PUGNAc treatment were modified in various cells having different susceptibility, prolonged cellular treatment with PUGNAc is known to elevate O-GIcNAc modification of numerous proteins without changing $N$-linked glycosylation or concentration of UDP-GICNAC and has been a useful tool for the study of cellular responses affected by O-GIcNAc modification (Mueller et al., 1998; Buren et al., 2002; Vosseller et al., 2002; Arias et al., 2004). Since primary adipocytes isolated from epididymal fat tissues can be incubated in the general culture condition for more than $24 \mathrm{~h}$ without changing insulin sensitivity based on GLUT4 translocation and glucose uptake (Li et al., 2001), we treated adipocytes with PUGNAc $(100 \mu \mathrm{M})$ for $12 \mathrm{~h}$ in this study. Our experimental condition, prolonged PUGNAc treatment (6 to $12 \mathrm{~h}$ ) to primary adipocytes successfully induced 0 -GICNAC modification on proteins (Figure 1). This result indicates that PUGNAc treatment applied to rat primary adipocytes can be used to inhibit $O$ GIcNAcase, resulting in a general increase in 0 GlcNAc modification on proteins, and is appropriate for studying the effect of O-GICNAc modification on insulin sensitivity.

It is noteworthy that the increased O-GIcNAc modification on proteins by prolonged PUGNAc treatment significantly reduced insulin-stimulated 2DG uptake without changing basal 2DG uptake (Figure $2 A$ and
$B$ ), indicating that PUGNAc indeed induces insulin resistance in rat primary adipocytes. In previous studies, Vosseller et al. (2002) found that PUGNAcinduced GICNAc modification of proteins is accompanied by insulin resistance in 3T3-L1 adipocytes, and Arias et al. (2004) also reported that PUGNAC decreases insulin-stimulated glucose uptake in rat skeletal muscle. Basal glucose uptake was not affected by PUGNAc in both studies. Our demonstration that insulin-stimulated glucose uptake in rat adipocytes was significantly decreased by prolonged PUGNAC treatment is consistent with these findings, and further supports that the increase of O-GICNAC modification on proteins in rat adipocytes is closely associated with the development of insulin resistance.

Both GLUT1 and GLUT4 are expressed in insulin sensitive tissues such as adipose and muscle tissues, and they participate in the basal and insulin-stimulated glucose uptake (Handberg et al., 1992). However, due to the relatively low abundance and insensitivity in the insulin-stimulated translocation of GLUT1, GLUT4 is the major player in the insulinstimulated glucose uptake of insulin sensitive tissues (Dean et al., 1998). To investigate the effect of $\mathrm{O}$ GIcNAc modification of proteins in GLUT4 translocation, we evaluated the effect of PUGNAc on the steady-state distribution of endogenous GLUT4. PUGNAc significantly reduced insulin-stimulated GLUT4 translocation from LDM to PM without any significant effect on the basal GLUT4 levels in the PM and LDM (Figure 3A). This suggests that impaired insulin-stimulated GLUT4 translocation to the $P M$ is a main cause of PUGNAc-induced insulin resistance observed in rat adipocytes.

At the molecular and cellular levels, how PUGNAc causes insulin resistance is an important question yet to be answered. It seems appropriate to suspect that the process whereby PUGNAc induces insulin resistance involves O-GICNAC modification of insulin signaling intermediates associated with GLUT4 translocation. There is a report that the infusion of high levels of glucosamine increased O-GIcNAc modification of IRS-1, IRS-2 and PI3K in skeletal muscle (Patti et al., 1999). More recently, Vosseller et al. (2002) demonstrated that IRS-1 and $\beta$-catenine were modified by 0 -GIcNAc in a PUGNAc-responsive manner in 3T3-L1 adipocytes. Even though numerous proteins modified with O-GICNAc were increased by PUGNAC treatment (Haltiwanger et al., 1998; Gao et al., 2000; Vosseller et al., 2002; Arias et al., 2004), their identities and functional significances were still largely unknown. Interestingly, our immunoprecipitation analysis with an O-GICNAC specific antibody clearly demonstrated that IRS-1 and Akt2, two key intermediates in the insulin-stimulated GLUT4 translocation and glucose uptake, were O-GICNAc modified by PUGNAC (Figure 4). The effect of PUGNAc on 0 GIcNAc modification of IRS-1 and Akt2 is quite selective. PUGNAc did not modify other insulin signaling intermediates such as IR, PI3K and PDK-1 (Figure 4). Insulin regulates GLUT4 translocation largely through the activation of IRS-1 via Tyr phosphorylation with 
subsequent activation/phosphorylation of its downstream effectors, such as PI3K, PDK-1, PKC- $\lambda \zeta$, and Akt2 (Saltiel and Pessin, 2002; Kanzaki and Pessin, 2003). However, the involvement of IRS-1 and/or Akt in insulin resistance resulted from O-GICNAc modification is controversial. In previous report, the reduced tyrosine phosphorylation of IRS-1 and -2 was observed in the glucosamine-treated rat skeletal muscle, whereas attenuation of insulin-stimulated phosphorylation of Akt was not accompanied (Patti et al., 1999). It was also reported that the elevated OGIcNAc modification by PUGNAc induced insulin resistance in skeletal muscle independent of attenuated phosphorylation of Akt and GSK3 $\alpha / \beta$ (Arias et al., 2004). On the other hand, there is a report that PUGNAC increases O-GICNAc modification on IRS-1, concomitant with the decreased insulin-stimulated activation of Akt in 3T3-L1 adipocytes (Vosseller et al., 2002). However, the O-GIcNAc modification of Akt and attenuation of insulin-stimulated IRS-1 phosphorylation were not observed. The defect in Akt activation in response to excessive flux through the HBP was also suggested in 3T3-L1 adipocytes (Heart et al., 2000). It is possible that different cells or tissues under various experimental conditions may explain controversial results. In this study, however, the treatment of PUGNAc caused drastic reductions in insulin-stimulated phosphorylation of IRS-1 and Akt2 (Figure $5 \mathrm{~A}$ and $\mathrm{B}$ ), clearly suggesting that $\mathrm{O}-\mathrm{GICNAC}$ modification on IRS-1 and Akt2 is the main cause in PUGNAc-induced insulin resistance in adipocytes.

O-glycosylation and O-phosphorylation are known to participate in modification of protein interaction and regulation of signal transduction by changing the protein reaction site through mutual interaction (Griffith and Schmitz, 1999; Cheng et al., 2000). Apparently, O-GICNAc modification of IRS-1 by PUGNAc produces no direct effect on its Tyr phosphorylation, but it is possible that $\mathrm{O}$-linked glycosylation on proximal Ser or Thr residue of IRS-1 is able to inhibit phosphorylation of Tyr residue, and that 0 -linked glycosylation of IRS-1 changes the conformation of its phosphorylation sites. For example, free fatty acids and cellular stress can result in increased Ser phosphorylation and reduced Tyr phosphorylation of IRS-1, thereby attenuating insulin signaling and causing insulin resistance in type 2 diabetes (Arias et al., 2004). PKC $\theta$ phosphorylates IRS-1 at Ser residues and subsequently impairs IRS-1 Tyr phosphorylation and downstream activation of Akt2 (Kellerer et al., 1998; Lawrence et al., 1990a). Undoubtedly more work is needed to determine the identities of 0 GIcNAc-modification sites and molecular events underlying attenuation of insulin-stimulated phosphorylation in the future.

In this study, PUGNAc treatment showed no effect on the expression level of GLUT4 (Figure 3). It is consistent with the previous report that HBP-mediated insulin resistance does not result from reduced GLUT4 expression (Nelson et al., 2000). However, we found that O-GICNAc modification of GLUT4 was increased in the insulin-responsive glucose transporter storage pool by PUGNAc treatment (Figure 6). It has been also reported that O-GICNAC modification of GLUT4 was increased in GLUT1-overexpressing muscle cells (Buse et al., 2002). It is interesting to note the significance of this modification. A number of early studies described the functional significance of GLUT4 phosphorylation in adipocytes (Lawrence et al., 1990a; 1990b, Begum et al., 1993). These studies showed that a relatively minor fraction of GLUT4 in adipocytes is in the phosphorylated state, and that insulin affects this steady-state level of GLUT4 phosphorylation only slightly, which leads to the conclusion that GLUT4 phosphorylation may not play a significant role in insulin-induced GLUT4 recruitment (Lawrence et al., 1990b; Begum et al., 1993). Nevertheless, the possible reciprocal regulation between GLUT4 phosphorylation and $\mathrm{O}$-glycosylation needs further investigation to clarify the insulin resistance mechanism.

In conclusion, O-GICNAc modification as a new regulatory signal is an important process involved in glucose uptake and insulin signaling with the development of insulin resistance in rat adipocytes. Our results clearly show that the treatment of PUGNAc is directly correlated with the elevation of O-GICNAC protein modifications and the development of insulin resistance in rat primary adipocytes. It is also clear in our data that the elevated O-GICNAc modification of IRS-1 and Akt2 by PUGNAc is closely associated with the reduction of insulin-stimulated phosphorylations of IRS-1 and Akt2. Here, we suggest that the increase of $\mathrm{O}-\mathrm{GICNAC}$ modifications on insulin signal pathway intermediates such as IRS-1 and Akt2, and the reduction in insulin-stimulated phosphorylation of IRS-1 and Akt2 are associated with the development of insulin resistance in PUGNAc-treated rat primary adipocytes.

\section{Acknowledgement}

This work was supported by Korea Research Foundation Grant (KRF-2002-003-E00021).

\section{References}

Arias EB, Kim J, Cartee GD. Prolonged incubation in PUGNAc results in increased protein $\mathrm{O}$-Linked glycosylation and insulin resistance in rat skeletal muscle. Diabetes 2004; 53:921-30

Baron AD, Zhu JS, Zhu JH, Weldon H, Maianu L, Garvey WT. Glucosamine induces insulin resistance in vivo by affecting GLUT 4 translocation in skeletal muscle. Implications for glucose toxicity. J Clin Invest 1995;96:2792-801

Begum N, Leitner W, Reusch JE, Sussman KE, Draznin B. GLUT-4 phosphorylation and its intrinsic activity. Mechanism of $\mathrm{Ca}^{2+}$-induced inhibition of insulin-stimulated glucose transport. J Biol Chem 1993;268:3352-6

Brownlee M. Biochemistry and molecular cell biology of diabetic complications. Nature 2001;414:813-20

Bryant NJ, Govers R, James DE. Regulated transport of the 
glucose transporter GLUT4. Nat Rev Mol Cell Biol 2002;3: 267-77

Buren J, Liu HX, Jensen J, Eriksson JW. Dexamethasone impairs insulin signalling and glucose transport by depletion of insulin receptor substrate-1, phosphatidylinositol 3-kinase and protein kinase $B$ in primary cultured rat adipocytes. Eur $\mathrm{J}$ Endocrinol 2002;146:419-29

Buse MG, Robinson KA, Marshall BA, Hresko RC, Mueckler MM. Enhanced O-GICNAc protein modification is associated with insulin resistance in GLUT1-overexpressing muscles. Am J Physiol Endocrinol Metab 2002;283:E241-50

Cheng X, Cole RN, Zaia J, Hart GW. Alternative O-glycosylation/O-phosphorylation of the murine estrogen receptor beta. Biochemistry 2000;39:11609-20

Comer FI, Hart GW. O-Glycosylation of nuclear and cytosolic proteins. Dynamic interplay between O-GIcNAc and O-phosphate. J Biol Chem 2000;275:29179-82

Cushman SW, Wardzala LJ. Potential mechanism of insulin action on glucose transport in the isolated rat adipose cell. Apparent translocation of intracellular transport systems to the plasma membrane. J Biol Chem 1980;255:4758-62

Dean DJ, Brozinick JT Jr, Cushman SW, Cartee GD. Calorie restriction increases cell surface GLUT4 in insulin-stimulated skeletal muscle. Am J Physiol 1998;275:E957-64

Dong DL, Hart GW. Purification and characterization of an O-GIcNAc selective $N$-acetyl-beta- $D$-glucosaminidase from rat spleen cytosol. J Biol Chem 1994;269:19321-30

Gao Y, Parker GJ, Hart GW. Streptozotocin-induced beta-cell death is independent of its inhibition of O-GIcNAcase in pancreatic Min6 cells. Arch Biochem Biophys 2000;383:296302

Giaccari A, Morviducci L, Zorretta D, Sbraccia $P$, Leonetti F, Caiola S, Buongiorno A, Bonadonna RC, Tamburrano G. In vivo effects of glucosamine on insulin secretion and insulin sensitivity in the rat: possible relevance to the maladaptive responses to chronic hyperglycaemia. Diabetologia 1995;38: 518-24

Griffith LS, Schmitz B. O-linked N-acetylglucosamine levels in cerebellar neurons respond reciprocally to pertubations of phosphorylation. Eur J Biochem 1999;262:824-31

Haltiwanger RS, Grove K, Philipsberg GA. Modulation of $O$-linked $\mathrm{N}$-acetylglucosamine levels on nuclear and cytoplasmic proteins in vivo using the peptide O-GIcNAc-beta- $N$ acetylglucosaminidase inhibitor $O$-(2-acetamido-2-deoxy- $D$ glucopyranosylidene)amino-N-phenylcarbamate. J Biol Chem 1998;273:3611-7

Handberg A, Kayser L, Hoyer PE, Vinten J. A substantial part of GLUT1 in crude membranes from muscle originates from perineurial sheaths. Am J Physiol 1992;262:E721-7

Heart E, Choi WS, Sung CK. Glucosamine-induced insulin resistance in 3T3-L1 adipocytes. Am J Physiol Endocrinol Metab 2000;278:E103-12

Hebert LF Jr, Daniels MC, Zhou J, Crook ED, Turner RL, Simmons ST, Neidigh JL, Zhu JS, Baron AD, McClain DA. Overexpression of glutamine:fructose-6-phosphate amidotransferase in transgenic mice leads to insulin resistance. $\mathrm{J}$ Clin Invest 1996;98:930-6
Kanzaki M, Pessin JE. Insulin signaling: GLUT4 vesicles exit via the exocyst. Curr Biol 2003;13:R574-6

Kellerer M, Mushack J, Seffer E, Mischak H, Ullrich A, Haring HU. Protein kinase $C$ isoforms alpha, delta and theta require insulin receptor substrate-1 to inhibit the tyrosine kinase activity of the insulin receptor in human kidney embryonic cells (HEK 293 cells). Diabetologia 1998;41:833-8

Kim BW, Choo HJ, Lee JW, Kim JH, Ko YG. Extracellular ATP is generated by ATP synthase complex in adipocyte lipid rafts. Exp Mol Med 2004a;36:476-85

Kim J, Min G, Bae YS, Min DS. Phospholipase D is involved in oxidative stress-induced migration of vascular smooth muscle cells via tyrosine phosphorylation and protein kinase C. Exp Mol Med 2004b;36:103-9

Laemmli UK. Cleavage of structural proteins during the assembly of the head of bacteriophage T4. Nature 1970;227: 680-5

Lawrence JC, Jr., Hiken JF, James DE. Phosphorylation of the glucose transporter in rat adipocytes. Identification of the intracellular domain at the carboxyl terminus as a target for phosphorylation in intact-cells and in vitro. J Biol Chem 1990a;265:2324-32

Lawrence JC Jr, Hiken JF, James DE. Stimulation of glucose transport and glucose transporter phosphorylation by okadaic acid in rat adipocytes. J Biol Chem 1990b;265:19768-76

Lee W, Ryu J, Hah J, Tsujita T, Jung CY. Association of carboxyl esterase with facilitative glucose transporter isoform 4 (GLUT4) intracellular compartments in rat adipocytes and its possible role in insulin-induced GLUT4 recruitment. J Biol Chem 2000a;275:10041-6

Lee W, Ryu J, Souto RP, Pilch PF, Jung CY. Separation and partial characterization of three distinct intracellular GLUT4 compartments in rat adipocytes. Subcellular fractionation without homogenization. J Biol Chem 1999;274:37755-62

Lee W, Ryu J, Spangler RA, Jung CY. Modulation of GLUT4 and GLUT1 recycling by insulin in rat adipocytes: kinetic analysis based on the involvement of multiple intracellular compartments. Biochemistry 2000b;39:9358-66

Li D, Randhawa VK, Patel N, Hayashi M, Klip A. Hyperosmolarity reduces GLUT4 endocytosis and increases its exocytosis from a VAMP2-independent pool in 16 muscle cells. J Biol Chem 2001;276:22883-91

Liu H, Xiong S, Shi Y, Samuel SJ, Lachaal M, Jung CY. ATP-sensitive binding of a $70-\mathrm{kDa}$ cytosolic protein to the glucose transporter in rat adipocytes. J Biol Chem 1995; 270:7869-75

Marshall S, Bacote V, Traxinger RR. Discovery of a metabolic pathway mediating glucose-induced desensitization of the glucose transport system. Role of hexosamine biosynthesis in the induction of insulin resistance. J Biol Chem 1991;266:4706-12

Martz A, Mookerjee BK, Jung CY. Insulin and phorbol esters affect the maximum velocity rather than the half-saturation constant of 3-0-methylglucose transport in rat adipocytes. J Biol Chem 1986;261:13606-9

McClain DA, Lubas WA, Cooksey RC, Hazel M, Parker GJ, Love DC, Hanover JA. Altered glycan-dependent signaling 
induces insulin resistance and hyperleptinemia. Proc Natl Acad Sci USA 2002;99:10695-9

Mueckler M. Facilitative glucose transporters. Eur J Biochem 1994;219:713-25

Mueller WM, Gregoire FM, Stanhope KL, Mobbs CV, Mizuno TM, Warden $\mathrm{CH}$, Stern JS, Havel PJ. Evidence that glucose metabolism regulates leptin secretion from cultured rat adipocytes. Endocrinology 1998;139:551-8

Nelson BA, Robinson KA, Buse MG. High glucose and glucosamine induce insulin resistance via different mechanisms in 3T3-L1 adipocytes. Diabetes 2000;49:981-91

Patti ME, Virkamaki A, Landaker EJ, Kahn CR, Yki-Jarvinen $\mathrm{H}$. Activation of the hexosamine pathway by glucosamine in vivo induces insulin resistance of early postreceptor insulin signaling events in skeletal muscle. Diabetes 1999;48: 1562-71

Pessin JE, Thurmond DC, Elmendorf JS, Coker KJ, Okada $S$. Molecular basis of insulin-stimulated GLUT4 vesicle trafficking. Location! Location! Location! J Biol Chem 1999;274: 2593-6

Rossetti L, Hawkins M, Chen W, Gindi J, Barzilai N. In vivo glucosamine infusion induces insulin resistance in normoglycemic but not in hyperglycemic conscious rats. J Clin Invest 1995;96:132-40

Saltiel AR, Pessin JE. Insulin signaling pathways in time and space. Trends Cell Biol 2002;12:65-71

Snow DM, Hart GW. Nuclear and cytoplasmic glycosylation. Int Rev Cytol 1998;181:43-74

Sweeney G, Somwar R, Ramlal T, Volchuk A, Ueyama A, Klip A. An inhibitor of p38 mitogen-activated protein kinase prevents insulin-stimulated glucose transport but not glucose transporter translocation in 3T3-L1 adipocytes and L6 myotubes. J Biol Chem 1999;274:10071-8

Vosseller K, Wells L, Lane MD, Hart GW. Elevated nucleocytoplasmic glycosylation by 0 -GIcNAc results in insulin resistance associated with defects in Akt activation in 3T3-L1 adipocytes. Proc Natl Acad Sci USA 2002;99:5313-8

Watson RT, Pessin JE. Intracellular organization of insulin signaling and GLUT4 translocation. Recent Prog Horm Res 2001;56:175-93

Wells L, Vosseller K, Hart GW. Glycosylation of nucleocytoplasmic proteins: signal transduction and $0-$ GIcNAc. Science 2001;291:2376-8

Yki-Jarvinen H, Virkamaki A, Daniels MC, McClain D, Gottschalk WK. Insulin and glucosamine infusions increase 0 linked $\mathrm{N}$-acetyl-glucosamine in skeletal muscle proteins in vivo. Metabolism 1998:47:449-55

Zachara NE, Hart GW. The emerging significance of $O$ GICNAc in cellular regulation. Chem Rev 2002;102:431-8 